\title{
Article \\ Socially Vulnerable Youth and Volunteering in Sports: Analyzing a Brussels Training Program for Young Soccer Coaches
}

\author{
Evi Buelens ${ }^{1, *}$, Marc Theeboom ${ }^{1}$, Jikkemien Vertonghen ${ }^{1}$ and Kristine De Martelaer ${ }^{2}$ \\ ${ }^{1}$ Department of Sports Policy and Management, Vrije Universiteit Brussel, 1050 Brussels, Belgium; \\ E-Mails: evi.buelens@vub.ac.be (E.B.), marc.theeboom@vub.ac.be (M.T.), jikkemien.vertonghen@vub.ac.be (J.V.) \\ ${ }^{2}$ Department of Movement Education and Sports Training, Vrije Universiteit Brussel, 1050 Brussels, Belgium; \\ E-Mail:kdmartel@vub.ac.be \\ * Corresponding author
}

Submitted: 12 September 2014 | In Revised Form: 21 November 2014 | Accepted: 9 January 2015 | Published: 25 June 2015

\begin{abstract}
A considerable number of young Europeans live or risk ending up in socially vulnerable situations. Different social channels (e.g., education, on the job training, leisure) exist through which youths can enhance their chances to improve their social position. There is a growing belief that sports in particular can help personal and social development of socially vulnerable youths. Nevertheless, there is little understanding of the mechanisms through which sports can foster development. In addition to participating in sports, volunteering in sports is also regarded as providing developmental opportunities for socially vulnerable youths. Today, however, there is an underrepresentation of socially vulnerable youths in volunteering and volunteer training programs. A case study in Brussels was set up within a volunteer soccer training program focused on socially vulnerable youths. A qualitative research design was used to analyze developmental experiences of participants $(n=11)$ and program organizers $(n=3)$. The study also aimed to gain more insight into the mechanisms underlying the program. Participating youths indicated development in both technical and key competences. It is concluded that a systematic approach of the volunteer training program can play an important role in the development of competences of socially vulnerable youths both as a volunteer and an individual.
\end{abstract}

\section{Keywords}

socially vulnerable youth; sports; volunteer training program; youth development

\section{Issue}

This article is part of the special issue "Sport for Social Inclusion: Critical Analyses and Future Challenges", edited by Dr. Reinhard Haudenhuyse (Vrije Universiteit Brussel, Belgium) and Professor Marc Theeboom (Vrije Universiteit Brussel, Belgium)

(C) 2015 by the authors; licensee Cogitatio (Lisbon, Portugal). This article is licensed under a Creative Commons Attribution 4.0 International License (CC BY).

\section{Introduction}

It is estimated that at present $13.0 \%$ of young people (aged between 15 and 24) in the European Union are neither in education nor in employment (Eurostat, 2014). Recent data show increased youth unemployment rates in Europe (Eurostat, 2014; ILO, 2013). Lowand unskilled youths in Europe stand fewer chances of getting a job compared to their highly skilled peers. Ac- cording to Sourbron and Herremans (2013), the opportunities for young job seekers highly depend on their educational qualifications. Dierckx, Coene, Van Haarlem and Raeymakers (2013) indicated that an individual's or head of family's level of education is strongly linked to poverty risk, reflecting the lack of a higher qualification ensuing deprivation. Consequently, a considerable number of young Europeans live or risk ending up in socially vulnerable situations. 


\subsection{Enhancement of the Social Position}

According to Vettenburg (1998), causes of social vulnerability in youths are not only directly linked to the young people themselves, but are also closely associated with the situation in which they live. In other words, the wider societal context, with its institutions (e.g., justice, education, labor market, welfare, unemployment service, health care, etc.), are also potential causes. A number of social inequalities have been reported in relation to Belgian (Flemish) youths, such as in school careers (Vettenburg, 2011) and job opportunities (VDAB, 2012). Besides this necessary change on the institutional level, it has been indicated that a number of social channels exist through which youths can become more resilient and better prepared in dealing with their vulnerable situation, thereby enhancing their chances of getting out of or improving their situation. Lamote et al. (2013) concluded that to break out of the vicious circle of poverty, it is far more efficient to invest in the human capital of vulnerable households than in increased allowances or activation in the job market. Human capital is defined by the OECD (1998, p. 9) as "the knowledge, skills, competences and other attributes embodied in individuals that are relevant to economic activity". Coleman $(1988,1990,1994)$ described a close relationship between social capital and the development of human capital (i.e., education and employment skills and expertise). He views social capital as "the set of resources that inhere in family relations and in community social organization and that are useful for the cognitive or social development of a child or young person. These resources differ for different persons and constitute an important advantage for children and adolescents in the development of their human capital" (1994, p. 300). His interest is in community-based processes surrounding the development of human capital, which is, according to Coalter (2007), frequently emphasized in policy statements about the potential role of sports in social inclusion strategies. Different approaches have been reported with regard to investing in youths' human capital. Undoubtedly the most commonly used strategy is formal education. Heckman (2008) referred to the development of knowledge and skills in childhood as crucial for the efficiency of further development. However, school is often the first institution where it founders. Negative experiences, for example as a result of a distorted relationship between student and teacher (Vettenburg, 2011), often lead to fewer chances to develop knowledge and skills. This, in turn, results in fewer (or no) qualifications, leading to a vulnerable position in the job market. Besides, investment in human capital also occurs through on-the-job training (Heckman, 2000). However, according to Bollens and Heylen (2010), lower qualified employees are often underrepresented in these courses (mostly provided within the private sector) and in most cases only end up in training sessions for the unemployed (within the public sector).

Furthermore, traditionally, the broad domain of leisure has also been regarded as providing an opportunity to positively strengthen the human capital of the youth (e.g., Glover \& Hemingway, 2005). Sports, as one of the most popular leisure pastimes among youths (Vanhoutte, 2007), have long been viewed as a means of socialization as well. In addition, there is a growing belief that sports in particular can help the personal and social development of socially vulnerable youths. According to Haudenhuyse, Theeboom and Coalter (2012) sports are not only regarded by many youth welfare workers and local policy makers as an ideal way to reach out to at-risk youth, it is also believed that sports provide developmental opportunities for this group. Consequently, in recent years an increasing number of so-called sports-based developmental programs have been set up (Hartmann \& Kwauk, 2011). It has been indicated that these practices-also referred to as "sport-plus" initiatives (Coalter, 2007)-often seem to be more capable than other socio-cultural activities in attracting young people independently of their socio-economic background (Feinstein, Bynner \& Duckworth, 2006; Vanhoutte, 2007). According to different researchers (Crabbé, 2007; Haudenhuyse, Theeboom \& Nols, 2013; Hellison \& Walsh, 2002; Spaaij, 2009), sports can provide rich contexts for reaching out to socially vulnerable youth. Next to "sport-plus" initiatives, in which sports are used as the core activity and adapted in various ways to achieve "development" objectives, also "plus-sport" initiatives can be distinguished. In these initiatives social and health programs use sports, and especially its ability to bring together a large number of young people, to achieve some of their objectives (Coalter, 2007).

\subsection{The Promise of Sports}

However, in recent years, an increasing number of researchers have questioned the strong belief that often exists with regard to the developmental potential of sports (e.g., Coakley, 2011; Coalter, 2007; Darnell, 2007, 2010a, 2010b; Guest, 2009; Kidd, 2008; Levermore, 2008). Giulianotti (2004), for example, referred to these believers as 'sport evangelists' indicating that they lack a critical perspective on sport's actual value. According to Coakley (2011), sports are too often viewed as a simple and cost effective means of problem solving and improving life quality for individuals and society alike. Coalter (2007) mentioned three main categories of claims of possible outcomes of youth sports participation: (1) personal character development; (2) reforming "at-risk" populations; and (3) fostering social capital leading to future occupational success and civic engagement. Hartmann and Kwauk (2011) 
indicated that, despite a general lack of sound empirical evidence, this blind belief in sports has resulted in the provision of various sports-based developmental programs at the local and national level.

Moreover, Hartmann and Kwauk (2011) stated that there is very little understanding of the mechanisms through which sports can foster development through these sports-based practices. According to Coalter (2011), assumptions about how sports interventions contribute to achieving certain outcomes and the ways through which these outcomes can be attained, are seldom clearly formulated. Pawson (2006) indicated that we need to make a shift in the analysis and understanding of these types of social intervention programs from families of programs to families of mechanisms - the processes, experiences and relationships that might achieve desired impacts and, hopefully, outcomes.

\subsection{Individual Development Perspective}

In an attempt to impart more clarity on development through sports-based initiatives, Hartmann and Kwauk (2011) distinguished two different approaches to the relation between sports and development. They see a "dominant" vision in which many initiatives hold an idealized belief in the positive pro-social power of sports. In this vision, program organizers assume participation in their program automatically and inevitably results in developmental outcomes. Coakley (2011) referred to this view as a "carwash effect" - the assumption that sports participation among at-risk populations cleanses character and washes away personal defects so that young people become "acceptable" to those in mainstream society. Coalter (2013) indicated that an often-mentioned rationale for the fact that many of the sport-for-development programs are aimed at atrisk youth, besides the attractiveness of sports, is program organizers regarding these youths as being "in need of an intervention". He warned however of "the dangers of an environmental determinism that assumes that deprived communities inevitably produce deficient people who can be perceived, via a deficit model, to be in need of 'development' through sports" (Coalter, 2013, p. 3). The dominant vision suggests that the cause of social vulnerability is primarily situated at the individual level. Hartmann and Kwauk (2011) indicated that this vision is fundamentally reproductive; containing programs in which sports essentially reproduce established social relations. This vision is in contrast with an aspect of Vettenburg's (1998) social vulnerability theory which emphasizes the lack of authority of social vulnerable groups to equally participate in the wording of social values and norms. As such, little attention is paid to their specific needs and demands. As a result, these groups can benefit to a lesser extent from the support provided by social institutions in comparison to other groups. According to
Hartmann and Kwauk (2011) and Darnell (2010a), there is a need for an alternative approach to developmental sports-based practices that starts by critically looking at existing social hierarchy with its power relations and social inequalities. They labeled this approach "interventionist"; where development is a more radical vision of social change in which participants are empowered to critically take part in the transformation of not only their own experiences of society, but also of society itself.

Contrary to the dominant vision, where coaches are expected to teach values that youths need to better fit into society, the interventionist approach suggests coeducation of youngsters, coaches and program organizers. Development, in this sense, is according to Sharma (2008) not something that can be done to or for people, but is seen as a process that must be undertaken with others. According to Hartmann and Kwauk (2011), this more radical vision of development, developed by critical scholars, centers on processes of empowerment, emancipation, and liberation involving the full and active participation of those previously marginalized. Within this interventionist approach, education and social development take on an alternative meaning and application. Following Kincheloe (2008), true education (and by extension development) is no longer defined by the skills and knowledge deposited into learners by teachers, coaches, or social workers, but defined by its emancipatory and liberatory capacity. The social relationships and interactions with participants are considered to be the key factors in the interventionist approach. The ideas of Kincheloe (2008) are closely related to the work of Freire (1970/2008) who endorsed students' ability to think critically about their education situation. Central in Freire's work was the notion to enable students to recognize connections between their individual problems and experiences and the social contexts in which they are embedded. The goal of education, in this perspective, is to raise the awareness of individuals to existing structures and relations of oppression, in other words, to invest in the conscientization of socially vulnerable youths and their critical praxis (i.e., reflection and action upon the world and its structures in order to transform it). According to Hartmann and Kwauk (2011), who based their interventionist approach on the ideas of Freire and Kincheloe, sports are primarily a useful "hook" and can play a role in the development of youngsters. This happens not automatically or on its own, but with appropriate guidance and in combination with other programs and initiatives.

\subsection{Voluntary Work in Sports as a Tool for Development}

According to Auld (2008), one of the advantages attributed to sports participation is the building or extension of a person's social capital. Auld stated that alt- 
hough social capital can be produced anywhere, its production is most commonly associated with the third sector; of which sports is a significant component. Third sector organizations according to Auld (2008), can act as vehicles for individuals to connect with each other and display behavior that often (but not always) has elements of altruism and social responsibility. Putnam (2000) also referred to the importance of volunteering with regard to social capital. Half of the 14 independent measures that comprised what Putnam defined as a "social capital index" were associated with volunteering and voluntary organizations; according to Cuskelly (2008), most of which correlated highly with the overall index score.

Although volunteering holds pro-social behaviors that benefit others (e.g., Institute for Volunteering Research, 2002; Penner, 2002), it is widely believed that helping others is also beneficial for the volunteer as well (e.g., Wilson \& Musick, 1999). Smith (2010) stated that besides the social capital gain, volunteer work can also confer human capital. Moreover, Day and Devlin (1998) conceptualized volunteering as a method by which people can invest in their human capital. They concluded that people learn, amongst others, organizational and leadership, and speaking and writing skills through volunteering. Furthermore, according to different researchers (e.g., Johnson, Beebe, Mortimer, \& Snyder, 1998; Hart, Donnelly, Younnis, \& Atkins, 2007), the outcomes of volunteering for youth include personal development and risk avoidance, highlighting its relevance to development beyond engagement in civic society.

According to MacNeela and Gannon (2014), volunteering is also underpinned by shared characteristics of positive youth development, self-exploration and prosocial ethos. It is not surprising that a number of positive youth development programs have been set up around volunteering. Different researchers (e.g., Eley \& Kirk, 2002; Kay \& Bradbury, 2009) investigated youth sports volunteering training programs that provided training to equip young people with the skills to perform their roles as volunteers and with the initial confidence to perform these roles. Their findings indicated that involvement in a voluntary training program facilitated social connectedness by providing opportunities for young people to engage with others (i.e., young children, peers, teachers, club members, etc.) in their communities. In addition, fostering a greater awareness of the needs of others and the positive experience to be gained from these interactions was also found to be effective in facilitating social capital. It also proved to be beneficial to the development of human capital (e.g., transferable social skills; increased sense of selfworth; greater sense of altruism and citizenship) (Kay \& Bradbury, 2009). Eley and Kirk (2002) demonstrated the advantage of using volunteering in sports as a means for encouraging pro-social behavior, developing leadership skills and citizenship among young people.
Despite the fact that volunteering in sports is regarded as providing developmental opportunities for socially vulnerable youth (Kay \& Bradbury, 2009), today there is an underrepresentation of these youths in most programs that work with young volunteers (e.g., Eley \& Kirk, 2002; Kay \& Bradbury, 2009). However, this is hardly surprising given that it has been reported that education, income and social networks are considered to be the most consistent predictors of volunteering (e.g., Penner, 2002; Taylor, Panagoulas, \& Nichols, 2012; Wilson, 2000). Apart from these participation constraints, at present there is no clear understanding of what the actual developmental impact of a voluntary training program on socially vulnerable youth can be. Nor is there insight into the active ingredients (or mechanisms and conditions) under which possible developmental outcomes can be generated for this group. Because of this knowledge gap, a study investigating a training program for young soccer coaches targeting socially vulnerable youth in Brussels was conducted.

\subsection{Being Young in Brussels}

Before turning to the case study, we will provide some more information regarding the situation of youth living in Brussels, the capital of Belgium and often regarded as the capital of Europe. The city has a young and ethnically diverse population. Almost one third of the population is between 15 and 34 years old (29.8\%) and has no Belgian nationality (32.6\%) (Brussels-Capital Health and Social Observatory, 2013). In 2009, three out of four of its newborns (74.3\%) had a mother of foreign origin (Brussels-Capital Health and Social Observatory, 2013). Similar to most other major European cities, there is a substantial group of young people living in socially vulnerable situations. According to Sourbron and Herremans (2013), the position of the Brussels youth in the labor market is one of the worst in Europe, with $36.4 \%$ being unemployed. In Brussels $18.7 \%$ of youths are neither in education nor in employment or training (NEET) (Eurostat, 2013), which is much higher than the average for the whole country (Belgium (12.7\%)) and Europe (13.0\%) (Eurostat, 2013). Half of all young job seekers in Brussels have low qualifications (compared to the Belgian average of $30 \%$ ) and a majority of them (61.9\%) has been looking for a job for more than six months. In Flanders (the northern Dutchspeaking part of Belgium) the efflux of young adults with no qualifications and therefore fewer chances in the labor market is highest in Brussels (Lamote et al., 2013).

\section{Brussels Case Study}

The case study described in the present paper analyzed a soccer coach training program for male disadvantaged youth living in Brussels. The program was part of a 6-year project set up by a youth work organization 
"Youth and City" ("Jeugd en Stad"-JES), with the aim of strengthening seven Brussels soccer clubs operating in deprived inner-city areas in playing a social role. The clubs, which are primarily run by volunteers of foreign origin, all emphasize the social role they can play in their neighborhood. However, the clubs are all facing a number of challenges, such as dealing with ethnically diverse memberships and the socially vulnerable backgrounds of many of their young players, as well as the negative image they have among local authorities and "native" Belgian clubs. The initial program's strategy of JES in 2007 in order to strengthen the clubs was to support the participating clubs on the organizational level, more specifically to optimize their managerial and structural functioning (e.g., improvement of administrative and communicative competences, overall structure, image, parent involvement, volunteer recruitment, etc.). However, this strategy turned out to be a long term process with limited immediate concrete results. In an evaluation study of this program Haudenhuyse and Theeboom (2008) concluded that these social surplus goals were not achieved as most clubs were dealing with major organizational problems. They concluded that building a club with a clear structure was the primary condition of working towards sport-plus goals; a condition that had not yet been fulfilled at that time. In 2010, a more direct approach was introduced with a focus on developing young volunteers in the participating clubs. This resulted in setting up a coach training program targeting adolescent club members. The program was organized during three consecutive soccer seasons (from September 2010 to May 2013). During each soccer season the program consisted of two clusters of four preparatory courses followed by an intensive week including approximately 40 young children. During the course of the program, 24 preparatory courses and six intensive weeks were organized. As a result, the program focused on individual development. The program organizers considered training volunteers as an indirect route to strengthening the clubs bottom-up. However, the focus of our study was on the volunteer training program (i.e., gaining more insight into the underlying mechanisms) and the developmental experiences of the participating youngsters as individual development was the primary goal of the program.

\subsection{Approach Used in the Investigated Program}

Central in the approach was the use of a so-called competence model with the intention of enabling the participating adolescents to acquire technical, as well as a number of general "key" competences. The former related to sports didactical, animation and pedagogical skills. The latter referred to competences that are considered to be transferable to other domains of life (e.g., school, leisure, work). Among others, the second type of competences included good listening and communication skills, providing and coping with feedback, personal and social responsibility, showing flexibility and (self)discipline, collaborative behavior, self-reflection, taking initiative, empathy, planning and organizational skills. The basic idea was that through helping young volunteers to acquire these skills, the human capital of the clubs would increase and could bring about changes in the long run, resulting in stronger clubs. Due to its additional emphasis on key competences, in addition to more technical formation, the program distinguished itself from existing sports coach formation initiatives in Flanders. It therefore provided an interesting case to look at the extent to which coach education programs might be able to develop competences of socially vulnerable youths through the use of sports.

\subsubsection{Competence Model}

Every technical competence domain focused on different technical competences and consisted of five different levels. This tiered approach was aimed at a vertical evolution (i.e., development). The first domain dealt with the competences relating to sports techniques and sports didactics. Youths started as assistant coaches and were gradually given more responsibilities until they became an independent full coach (and in turn had to supervise assistant coaches). Within a second domain, emphasis was on developing an "animator". Based on prior experiences of an existing course developed by the youth work organization, youths gradually learned how to prepare and guide side activities for young children. The course made use of different character roles, each of which addressed different competences. At the simplest levels, youths worked on technical competences relating to the roles of "friend" (empathy with target audience, respect) and "clown" (entertaining, motivation). Advancing in difficulty, the roles of "guide" (leadership, explanation of activities) and "referee" (responsibility, boundaries, making rules and living up to them) were used. Finally, the roles of "builder" (organization of an activity, cooperation) and "inventor" (creativity, flexibility regarding animation activity) were introduced. The third technical competence domain related to pedagogical skills as a more general support to the training sessions and side activities. The focus evolved from personal to social responsibility towards others. The key competences related, among other things, to empathy, listening skills, communication skills, social skills, taking initiative, flexibility, planning and organizing skills and self-reflection. They were introduced gradually and combined with the different technical competence levels and domains.

\subsubsection{Rating Instrument}

The different levels and domains within the compe- 
tence model were used to provide participants with insight into their own development and position themselves by means of a rating instrument. The positioning was done both by the youths themselves and the accompanying program organizers. For the technical competence domains, a five-point rating system was used enabling the respondents to assess the different competences, ranging from "perfectly able/knowledgeable" to "not able/knowledgeable at all". The rating instrument also revealed which key competences were important at each level. For every key competence, youths were asked about their personal meaning and its practical relevance. On the basis of these outcomes, the competences were further developed. At the end of each intensive week, youths were evaluated with regard to their positioning within the competence model. Development (if any) was also visualized by indicating their previous and current levels.

\subsection{Method}

A qualitative research design was used to analyze experiences of participants and accompanying program organizers with regard to their involvement in two intensive weeks and eight preparatory courses during the 2012-2013 soccer season. In the present study individual semi-structured in-depth interviews were used. According to Jones (1985), adolescents need to describe their experiences in their own words in order to best understand their meaning. Similar to other researchers that investigated experiences of socially vulnerable youth and sports interventions (e.g., Haudenhuyse, Theeboom, Nols, \& Coussée, 2014), an interpretative phenomenological approach (IPA) was used. This method allowed us to understand the data from the perspective and experience of the interviewees relating to the shared phenomenon (with peers and program organizers) of participating in the volunteer training program. In this respect, both the perspective from the program organizers (youth workers) and the participating youths were relevant.

\subsubsection{Youths}

The program was aimed at socially vulnerable youths living in disadvantaged areas in Brussels, active as soccer trainers in specific clubs in Brussels. The goal was to offer these youths a longitudinal developmental trajectory. They were actively encouraged to be involved for the duration of the program; unfortunately some dropped out. Others joined the group later on. Youths could also (re)start at any time. As a result, the participating youths during the 2012-2013 program had different levels of competences making the program different for each individual. However, the fact that during the last season youths with a different level participated in the program was considered to be a good opportunity for the study. This allowed us to include both "experienced" and "less experienced" youths, adding a cross-sectional dimension to the data.

During the 2012-2013 season all participating youths attending one or both intensive weeks were interviewed. In total, the first author conducted 17 interviews with 11 different male youths. The average age of the participants was 17.64 years $(S D=1.63)$ and all were active in the same soccer club in Brussels. The other clubs involved in the initial program did not have adolescent coaches or were not interested in the coach training program and were not included in the present study. All participants lived in disadvantaged areas in Brussels and had predominantly North African roots. Most youths were trilingual (Arabic, Dutch, French), but according to the program organizers they mastered none of the languages perfectly to be able to express any subtleties, causing frustration and leading to occasional negative behavior. The majority of participants were in technical or vocational education. Only one of them received more general education preparing him for higher studies.

The mean duration of the interviews was 31 minutes. During each intensive week we interviewed all participating youths. This resulted in six youths being interviewed twice (they participated in both intensive weeks within an interval of four months) and five youths who were interviewed once (three during the first intensive week and two during the second intensive week). Two interview guides were constructed for both intensive weeks. The first interview guide started with a brief background inquiry followed by an openended, descriptive questions section regarding the situation of the youth in their clubs, how they look at themselves as coaches, the intensive weeks and preparatory courses and the possible impact of the program on their personal lives and the clubs. During the second interview, the focus was more on possible impact and learned lessons with regard to the previous intensive week and preparatory courses and the differences between the first intensive week and the second.

\subsubsection{Program Organizers}

The three program organizers, all youth workers, were interviewed twice by the first author. The first interview was on an individual basis during the first intensive week. It primarily included questions concerning the actual approach. The second interview was a group interview immediately after the first intensive week in which all program organizers were asked to reflect on the experiences of the participating youths.

All interviews were tape-recorded and, following a verbatim transcription, analyzed inductively afterwards. In the first step of the analysis, the researchers read the transcripts several times separately, looking for meaningful units of information (i.e., segments of 
text that were comprehensible by themselves, that contained one specific idea, episode, or piece of information (Tesch, 1990)), as well as similar patterns and concepts. Researchers' independent analyses were then followed by discussions to resolve conflicting interpretations with regard to coding and themes. Codes with a similar meaning were then grouped together leading to the development of different (sub)themes. A computer software program, Nvivo 10 , was used to assist with the coding and sorting of the data.

In addition to interviewing youths and program organizers, the first author also conducted participant observations during both intensive weeks. Finally, document analysis of the yearly reports of the program organizers was carried out. The observations and the document analysis provided us more insight into the program and enabled us to interpret the data within its specific context.

\section{Results-Discussion}

The aim of the study was on the one hand to gain more insight in the underlying mechanisms of the volunteer training program. On the other hand we wanted to gain more insight into the individual development of the participating youngsters. Therefore, findings of the study are presented thematically (i.e., approach of the volunteer training program, and developmental experiences) and occasionally illustrated using raw data (i.e. quotes).

\subsection{Approach of the Volunteer Training Program}

\subsubsection{Long-Term Program}

Both program organizers as participants experienced the extended length of the program as a positive factor. The duration of the program enabled the building of relations of trust with the accompanying program organizers and competence development on different levels.

It's an audience where the group is rather important. If you take them to an intensive week a few times, the longer they know you, the more they trust you and the more you can say to them. (Program organizer)

Experience, knowledge and expertise regarding the different competence domains and the way in which these are transferred, as well as giving relevant and meaningful feedback contributed to these relationships, and were positively valued by the participants.

Yes, they are constantly present, just to discuss things with you....At the club, sometimes you're on your own. (Hamir)
The youths also indicated that their relation with the children improved during the course of the program and that the parents respected them more. It was also mentioned that the duration of the program provided opportunities for experiential learning.

During each intensive week you learn something. Every day, every moment, every second, you see different things and different situations. You see good and bad moments. And that gives you a lot of experience, you see? And you learn a lot thanks to these experiences and moments. (Bilal)

According to the program organizers, the fact that participants had different experience levels had a positive influence on the competence development of all youths. This is in line with Dryfoos (1990) who stated that adolescents need to have the opportunity for interaction with positively oriented peers and for involvement in roles in which they can make a contribution to the group. The participating youngsters endorsed this and found it meaningful to help and learn from each other.

There are different kinds of coaches, there are young coaches who attend for the first time and we are here to help them. I'm at level 4, they're at level 1 , and we train the children together. They learn from me, sometimes I can help them. (Adnan)

The program organizers also noticed that the participants had difficulties with being critical and giving feedback to one another at first, but that this clearly improved the longer they stayed in the program. The same appeared to be true for taking up responsibilities in their club (e.g., organizing tournaments on their own initiative).

\subsubsection{Experiential Learning Trajectory}

The practice-based approach of the program was highly appreciated by the participants. Youths were very positive about the preparatory courses, which dealt with the different technical competence domains, and the methods that were used during the intensive weeks (e.g., the role playing, team building).

Because everything I saw and heard during the courses, I also saw here. We played games with the coaches, using name tags that called ourselves friend, builder, doctor or referee. If there is a fight, you have to interfere and act like the referee. Or as builder you have to help someone to build or to put something away. (Hamir)

The data showed that a practice-oriented approach involving learning by doing, working with life-like situa- 
tions and the concretization of abstract concepts was well-received by the participants. The program organizers also indicated that the intensive weeks created a context that differs from the daily environment of the youths, thereby enabling learning opportunities.

A green environment is something completely different. A different infrastructure, peace and quiet, a whistling bird instead of a noisy train. The surroundings, a forest, new inputs, new experiences, all add value.... These guys are tough if you meet them on the subway, but put them in the dark at midnight, they're scared and come to you for comfort. (Program organizer)

This was also confirmed by youths who valued a safe place and the fact that they could return each intensive week to the same familiar environment. Other authors (Coalter, 2007; Fraser-Thomas, Côté, \& Deakin, 2005) have also emphasized the importance of a safe and supporting environment (physically, psychologically and emotionally) for this population.

Both youths and program organizers regarded the experiential learning with opportunities for "trial-anderror" by participants as one of the most important factors of the program. Within this experiential learning trajectory the program organizers are playing an important role.

Experiential learning has to put the focus on the youngsters because it will increasingly give them the feeling that they can handle the situation themselves. In part, they determine themselves what the problem is and what they will tackle. They experience a problem and then ask themselves what they can do. You have to try to stimulate their independence and not merely teach them to do certain tasks. (Program organizer)

What I like was that they let us make mistakes. They didn't say, "you don't have to do that", but they let us make our mistakes and at the end of the day we meet and they tell us what we did. They never say, "that was bad". They always try to tell us in a nice way. They let us make mistakes and that's how you learn the most. (Tarik)

According to the program organizers and youngsters, this kind of approach is often missing in other contexts.

[Difference with supervisors at the club?] "Yes, I think they are more present. You lead a training session and they say what's not good, what you can change. They help you when you're stuck. At the club, they have a quick look, quick quick, that's not good. Here, they say what's good, they try to see what you're capable of, just by asking questions. (Ayoub)
An important aspect of the guidance approach was related to the positive experiences with the intense and frequent interactions (both formal and informal) between participants and program organizers. For example, the youths highly valued the group discussions with the coaches and peers at the end of every day, but at the same time found them difficult. Other authors (e.g., Hellison, 1995) have also reported the effectiveness of similar strategies in dealing with socially vulnerable youths.

Group discussions are good because you learn from your own mistakes...it is easy for everyone to give comments on themselves, but it is more difficult to comment on other people. (Ayoub)

We can learn from each other's mistakes. When you've done something wrong and you don't realize this yourself, other people can tell you. (Hamir)

\subsubsection{Competence Model and Rating Instrument}

Both the participants and program organizers highly appreciated the use of a competence model which emphasized technical as well as key competences and the approach of self-reflection by the self-rating instrument.

The interesting thing is that they begin to think about themselves, which is an entirely different approach than just saying what they have to do. Now, they start to think on their own about how they work, the mistakes they make, and how they can try to improve. (Program organizer)

The data also showed that both the competence model and the rating instrument were regarded by the program organizers as critical elements within the approach of visualizing developmental experiences. Youths also appreciated this.

Before I joined the intensive week, I didn't know this. And thanks to this [the competence model] you know what level you are. Before, you didn't think about your level. I just coached. But thanks to [the competence model] I know more or less what my level is and what my next aim is. (Tarik)

We never get self-evaluation at school. It is weird that you never have to assess yourself. Here, they encourage you to do it. (Abel)

The differences in the levels of the competence model were explained by making reference to themes that were popular among the youngsters and to their social environment (e.g., international soccer competition), as this helped the youngsters to accurately assess what the different levels meant. 
For example, they showed five pictures of coaches from the different international soccer competitions. And for instance Belgium was the lowest level...and Spain the highest. This showed us where you think you were as a coach on the sports didactical level. (Bilal)

The program organizers deliberately opted for a system in which the youths assessed themselves to stimulate self-reflection. This process was not easy for some youngsters, as they sometimes overrated themselves. However, the youngsters indicated that it stimulated them afterwards to actively pursue higher competence levels. The program organizers stressed that it stimulated youths' ability to cope independently and they regarded this as an important factor in this respect.

\subsection{Developmental Experiences}

In order to facilitate personal developmental through participation in the volunteer training program, youths first have to take part in the program. One crucial influencing factor turned out to be the development of a safe and supporting environment in the soccer club where youths feel at home and are encouraged to take up voluntary tasks (i.e., as a coach) and participate in the program.

With regard to their sustainable participation in a soccer club, a number of youths emphasized the familial character of the club as an important factor. They referred to it as their second home and said that they spend most of their free time there (ranging from three times a week to daily), partly because it gives them something to do (i.e., meaningful pastime).

I realized that I always sat at home and I found that I had already missed too many things. I wanted to do something big and now at least I have something to do every day. (Ayoub)

My parents approve of the fact that I'm doing this. I'm living in a disadvantaged area and by coaching a team I stay away from the street. It's more reassuring for parents knowing their child spends his spare time at the soccer club. (Tarik)

As the youths experienced the soccer club as a safe and supportive environment, they were motivated to be involved in the volunteer training program. In this way the program organizers and participants could start working towards their individual development.

The youths in our study indicated that they had personally changed during the volunteer training program (e.g., increased insight into their own competences and behavior and an increased self-confidence with reference to their function as coach). Acquiring insights into their own personal evolution and actually improving was regarded as important. For the majority of the participants, this was the most important reason for participating in the program.

The aim of the intensive week? That I start the second intensive week in the way I ended the first intensive week. That I start there with that experience. And that I end there with more experience. (Hamir)

Youths indicated they had developed themselves within the different technical competence domains (i.e., sports didactical, organizational and pedagogical). They also indicated that they had transferred the acquired knowledge both during the intensive week as well as afterwards in their own training at the club.

Learning to communicate with the children....I've learned a lot and now I communicate better and my training sessions are better. (Hamir)

What they teach us is how you have to deal with children. How you have to punish them. Prevention is better than cure, as they say. (Tarik)

I learned to take the different animator roles into practice, for example referee, clown, friend, or builder. Dependent on the moment or the group I play a different role. Sometimes you have to be strict and act like a referee, in other cases you have to act like a friend or a clown and motivate children to take part. (Hamir)

The youths also mentioned having developed different key competences. These primarily related to taking responsibilities and initiative, setting goals and managing time.

What I mostly learned here was first and foremost to take initiative and responsibility. Because if you don't do that, nothing will happen. (Bilal)

The last time I didn't take initiative because I was ashamed, I was too afraid, but this time, I am less afraid to do something in the group. (Hamir)

In addition youths indicated that taking up responsibilities adds meaning to their lives.

Participants also stated to have made new and improved relations with peers and developed relationships with adults and children inside and outside the club (e.g. responsible youth trainers, program organizers) as well as improved social competences (e.g., collaborating as a team, communicating more effectively, dealing with feedback and debating skills, taking up social responsibility). They further indicated that the experiences made them think more clearly about their own behavior and attitude. 
I know I sometimes get angry too fast, for instance if I lose or if someone makes me uncomfortable because of what he says...now, I have more selfcontrol than before, I can just count to ten and pretend as if I wasn't listening. (Ayoub)

You see, youngsters nowadays are always alone on the streets, doings things that aren't right. My mind is 24 hours of the day on soccer. That's better than stealing or smoking or doing weird things. (Hamir)

Furthermore, the program organizers stressed the importance in the transfer of learned knowledge and expertise by the participants to other domains and situations (e.g., to add elements from the animator courses to the training sessions at their own club), as well as to their overall functioning as a coach at the club. Youths also indicated that they are applying things they learned during the program to their daily lives (e.g., better preparing things for school, keeping appointments, taking initiative or organizing activities at home).

I do that for instance in school and that's because I learned it here; to show respect and to be polite. (Anouar)

I have two little sisters and sometimes I entertain them at home and they really like it. I really want to work with children in the future. (Zakaria)

We learn here for instance: we learned the method to structure our training. This also occurs in the initiator course. We learned it here to take the initiator course. That way, I'm a little bit prepared. (Ayoub)

\section{Conclusions}

The present study has analyzed the experiences of socially vulnerable male youth participants in a voluntary soccer coach training program in Brussels. Unlike most other volunteer training initiatives in Belgium, this program emphasized the acquisition of more general competences besides technical coaching related skills. The study has tried to gain more insight into the specific approach that was used to facilitate developmental outcomes among its participants as well as to learn more about participants' experiences with this program.

\subsection{Interventionist Approach}

Based on the interviews with the program organizers we obtained more insight into the developmental approach that was used in the investigated program. We found different indications that the approach used within the investigated program is more situated within what Hartmann and Kwauk (2011) described as an interventionist approach. We based this assumption on the following characteristics of the program:

- Experiential learning, used as a central approach in the program, is consistent with the paradigm of empowerment. "Empowerment", described by many authors (see e.g., Rappaport, 1987; Van Regenmortel 2002, 2009; Zimmerman, 2000), is a multi-level construct. Empowerment looks amongst others, according to Van Regenmortel (2002, 2009), from an insider's perspective at the fact that an individual can also learn from their own experiences. Because of these experiences, youngsters can learn how to deal with similar or new situations. This self-gained experiential knowledge might then lead to a change in attitudes and new skills that offer, for their part, new opportunities to improve the socially vulnerable position of the youngsters. Empowerment thus shows these resemblances to the interventionist approach of Hartmann and Kwauk (2011) as it focuses on (the experiences of) the person himself.

- Within the investigated program, volunteering (in sports) was a key mechanism. Volunteering resembles the interventionist approach, as it is a process that is undertaken with others, holds an emancipatory capacity, and is undertaken by free will. Furthermore, according to Risler and Holosko (2009), volunteering can also contribute to the development of empowerment.

- Within the program the emphasis was on selffulfillment and development on a stepwise basis. The involvement of the youngsters increased gradually, at their own pace, in consultation with the youngsters and program organizers. In accordance to the interventionist approach, development in the investigated program was seen as a co-educational process between youngsters and program organizers. Important here was that the youngsters chose on which (key) competences they wanted to work, and where they wanted to focus (on animator, trainer), which gave them the necessary freedom.

- The program emphasized self-reflection as an important tool. Youngsters were encouraged to set a level for themselves by means of selfcontemplation. Guidance was stressed on both gaining insight into their competences and on stimulating their ability to cope on their own. In this way, youths did not feel told what to do. This can be linked to the interventionist approach as youths critically reflect on themselves and their situation.

- The youngsters were encouraged to vouch for each 
other (through collaboration between experienced and unexperienced youngsters). In this way, they are encouraged to learn from each other, which can be linked to the interventionist approach as, according to Sharma (2008), development is a process that must be undertaken with others.

However the operationalization of the interventionist approach described by Hartmann and Kwauk (2011) remained theoretical and a clear dichotomy between the dominant and interventionist approach is difficult to make, this study contributed to a better understanding of how an interventionist approach can be applied in practice. In this way we gained more insight in some of the underlying mechanisms of the program.

\subsection{Youths Developmental Experiences}

The interviews with both the youngsters and the program organizers showed during the voluntary sportsbased training, positive youth developmental experiences were manifested in different ways.

- Youngsters mentioned that they could develop their competences and gain more insight into themselves. Youngsters had positive developmental experiences with regard to their participation in the program. The youngsters in our study indicated that they personally changed during the program, which was endorsed by the program organizers. According to the youngsters, they developed within the different technical competence domains, as well as with respect to different key competences. These key competences were primarily related to taking responsibilities and initiative, setting goals and managing time. Additionally, the youngsters indicated that they acquired insights into their own personal competences, attitudes, behavior and evolution, which were regarded as important to them. Furthermore, the youngsters stated that their experiences made them think more clearly about their own behavior and attitude.

- Participants stated that they had made new and improved relationships with peers, and developed relationships with adults and children inside and outside (e.g., program organizers) the club. The findings revealed that the youngsters, as well as the program organizers, showed respect for each other and that a bond of trust was created. They also stated that they had improved their social competences (e.g., collaborating as a team, communicating more effectively, dealing with feedback and debating competences, taking up social responsibility). We can conclude that these youngsters were indirectly referring to the devel- opment of their social capital to both Putnams' (2000) bonding (close ties between friends; in this program, with other participants) and bridging (more distant ties; in this program, with the responsible of the youth trainers at the soccer club) as well as to Woolcocks' (2001) linking social capital (relationships between individuals and groups in different social strata; in this program, with the program organizers).

- Youngsters indicated that they transferred and applied the knowledge and competences acquired during the program to their daily lives (e.g., club, school, home).

Based on these findings we can conclude that the program invested in the human capital of the participating youngsters, not in a direct way (through formal education or on-the-job-training), but through informal learning. Crucial in the program is that the investment in youths' human capital is seen as the development of a broad set of resources (e.g., responsibility, goal setting, time management, as well as social competences (working together, communication, dealing with feedback, etc.)). This broader focus, beyond, for example, job specific knowledge and competences, is of relevance as findings show that the developed competences are transferable to other domains of life (e.g., club, school, home). Besides, the fact that the youths indicated they had developed their social capital is an important finding as different researchers (e.g., Coleman, 1988; Schuller, 2001) have stated that, however human capital is very powerful in his own terms, and an essential feature of prosperity, it cannot be taken out of its contexts of social relationships. According to Schuller (2001), social capital gives greater prominence, for example, to informal modes of learning, and the skills acquired through learning by doing.

The above-described developmental experiences of the youths within the program correspond well to different outcomes described in the positive youth development literature. For example, the current findings resemble three out of four main areas of youth development outlined by the American National Research Council and Institute of Medicine (NRCIM, 2002) (i.e., intellectual, psychological/emotional, and social development). There is also similarity with some of the 40 developmental assets from Benson (2006), both on the external (e.g., positive peer influence, etc.), as well as on the internal level (e.g., responsibility, planning, and decision making, etc.). Reference can also be made to "contribution", which is Lerner's sixth (additional) C in his 5 Cs of positive youth development (i.e., competence, confidence, character, caring/compassion, and connection) (e.g., Lerner et al., 2005). The youths in the present study were actively stimulated to prepare and organize training sessions and side activities for young- 
er children (both during the intensive weeks and at the club). Furthermore, participants reported experiences that can be classified in the personal and interpersonal processes of development as described by Dworkin, Larson and Hansen (2003) for youth in general.

\subsection{Limitations}

\subsubsection{Program}

As we described above (see 4.1), the investigated program shows, amongst others, resemblances with the interventionist approach of Hartmann and Kwauk (2011) as it focuses on (the experiences of) the person himself. However, the fact that the program organizers did not make an effort, or did very little, to the further development of youngsters in the club (e.g., offering (developmental) opportunities, guidance from club members) during and after the program is a limitation of the program. Participating in a youth development program alone ignores the wider societal causes of social vulnerability. As described in the introduction (Hartmann \& Kwauk, 2011; Vettenburg, 1998), also social institutions and policies, as possible reproducers and maintainers of social inequalities, need to be transformed to improve the situations that youths are living in. This underlies the fact that developing human capital cannot be seen apart from the broader context of our society. However, according to Coussée and Roets (2011), sports-based social interventions have their meaning, as they may offer contexts in which young people could acquire competences to give meaning to their lives and help them cope with and change difficult situations. It might be a relevant point of interest for further research concerning similar sport-for-developmentprograms to investigate how a context can be transformed in order to improve the situations socially vulnerable youths are living in.

\subsubsection{Study}

Based on the results of the present study, we tried to better understand the underlying mechanisms of the volunteer training program and the developmental experiences of the participants. However, we can formulate one major limitation with this respect.

On the one hand, we interviewed program organizers, who said that they applied a specific strategy, and on the other hand, youngsters who said that they were experiencing different kinds of things. However, three critical remarks can be made here. (1) Program organizers said they made use of an assessment tool to record the key competences, but when asked for an example, it became clear that in practice they did not use it. (2) We found that the elaboration of a method does not automatically lead to program organizers to use this application in the same way (e.g., program organ- izers attributed different interpretations to the same term (inter rater reliability), and were vague with regard to their own interpretations concerning the aims and strategies). (3) Our understanding of the developmental impact of the program might be influenced by the fact that we only considered the experiences of those who organized and participated in the program. Also, as criticized by Hartmann and Kwauk (2011), this might result in a distorted positive image. For further research it might be relevant to consider the views and experiences of those who did not (want to) participate or who dropped out.

These findings underline the differences between, on the one hand, the real and perceived impact of the program, and, on the other hand, between the real processes and perceived insight in them. This is in agreement with the findings of Coalter $(2007,2012)$ and Hartmann and Kwauk (2011) that program organizers and researchers are confronted with major difficulties in defining and measuring the impact of programs. Therefore, future research needs to focus on gaining more insight in the reality (i.e., the real impact and mechanisms). The use of a program theory might be useful in this regard, allowing program organizers and researchers to develop and analyze programs in a systematic way.

\subsection{Future Research}

As Pawson (2006) described, we need to shift analysis and understanding of social intervention programs from families of programs to families of mechanisms (i.e., the processes, experiences and relationships that might achieve their desired impacts and, hopefully, outcomes). We need, in other words, to gain more insight into the program theories of different sport-forchange programs. Program theory has been defined as "a plausible and sensible model of how a program is supposed to work" (Bickman, 1987, p. 5). It is, in other words, a sequence of presumed causes/actions/ processes and effects (Weiss, 1997). Program theory can be used to undertake consistent, robust, and comparable monitoring and evaluation of programs, which is lacking at this moment (e.g., Coalter, 2007, 2012; Coakley 2011). In addition, such an approach seeks to describe mechanisms in a systematic way, examine the theoretical underpinnings of programs as a basis for realistic evaluation and, mostly, provide some basis for generalization in order to inform future program design (Coalter, 2012). With regard to sports, few program theories are yet described. As a first step with regard to sport-for-development programs, Coalter (2012) developed a tentative program theory in an attempt to provide an overview of possible program elements, which is not definitive, but provides a template to situate other sport-for-development programs. Possible program elements are the approach to re- 
cruitment (inputs 1), nature of the participants and assumptions about them (inputs 2), nature of sports provision and the priority accorded to sport in the socialization process (outputs 1: sport, sport-plus or plussport), the nature of social relationships between program personnel and participants (outputs 2), the social climate of the program (outputs 3 ), the response of participants to these various stimuli (personal impacts), interim outcomes (e.g., taking responsibility), and strategic outcomes (e.g., employment).

Our research showed that analyzing a program on an inductive manner delivers different insights, but to truly understand the underlying mechanisms, future programs need to consider the development of a program theory that allows program evaluators and researchers to focus on evaluation in a structured and systematic way.

\section{Acknowledgments}

Funding of this research was provided by the Policy Research Centre on Sports, supported by the Flemish Government.

\section{Conflict of Interests}

The authors declare no conflict of interests.

\section{References}

Auld, C. (2008). Voluntary sport clubs: The potential for the development of social capital. In M. Nicholson \& R. Hoye (Eds.), Sport and social capital (1st ed., pp. 143-164). Oxford: Elsevier.

Benson, P. L. (2006). All kids are our kids: What communities must do to raise caring and responsible children and adolescents (2nd ed.). San Francisco: CA, Jossey-Bass.

Bickman, L. (1987). The functions of program theory. New Directions for Program Evaluation, 33, 5-18. doi:10.1002/ev.1443

Bollens, J., \& Heylen, V. (2010). Determinanten van de inzetbaarheid en de mate waarin ze beleidsmatig beïnvloedbaar zijn [Determinants of availability and the extent in which this is compliant by policy]. WSE Rapport Leuven. Leuven: Katholieke Universiteit Leuven. Steunpunt Werk en Sociale Economie / Katholieke Universiteit Leuven. HIVA-Onderzoeksinstituut voor Arbeid en Samenleving.

Brussels-Capital Health and Social Observatory. (2013). Youngsters in transition, the generation of adults. Brussels poverty report 2012. Brussels: Gemeenschappelijke gemeenschapscommissie

Coakley, J. (2011). Youth sports: What counts as "positive development"? Journal of Sport \& Social Issues, 35(3), 306-324. doi:10.1177/0193723511417311

Coalter, F. (2007). A wider social role for sport: Who's keeping the score? (1st ed.). London: Routledge.

Coalter, F. (2011). Sport development's contribution to social policy objectives. The difficult relationship between politics and evidence. In B. Houlihan \& $\mathrm{M}$. Green (Eds.), Routledge handbook of sports development (1st ed., pp. 561-578). London: Routledge.

Coalter, F. (2012). "There is loads of relationships here": Developing a programme theory for sportfor-change programmes. International Review for the Sociology of Sport, 48(5), 594-612. doi:10.1177/1012690212446143

Coalter, F. (2013). Sport for development: What game are we playing? (1st ed.). London: Routledge.

Coleman, J. S. (1988). Social capital in the creation of human capital. American journal of sociology, 94(Suppl. 1), S95-S120. doi:10.1086/228943

Coleman, J. S. (1990). Foundations of social theory (1st ed.). Cambridge, MA: Belknap Press.

Coleman, J. S. (1994). Foundations of social theory (1st Harvard University Press paperback ed.). Harvard: Harvard university press.

Coussée, F., \& Roets, G. (2011). Vrijetijdsbeleving van kinderen in armoede. Onderzoek in opdracht van de Vlaamse Gemeenschap, CJSM, Afdeling Jeugd. Eindrapport [Leisure time experiences of youngsters living in poverty. Research supported by the Flemisch community, CJSM, youth department. Final report]. Gent: Vakgroep Sociale Agogiek.

Crabbé, T. (2007). Reaching the "hard to reach": Engagement, relationships building and social control in sport based social inclusion work. International Journal of Sport Management and Marketing, 2(1/2), 27-40. doi:10.1504/IJSMM.2007.011388

Cuskelly, G. (2008). Volunteering in community sport organisations: Implications for social capital. In M. Nicholson \& R. Hoye (Eds.), Sport and social capital (1st ed., pp. 187-203). Oxford: Elsevier.

Darnell, S. C. (2007). Playing with race: Right to play and the production of whiteness in "development through sport". Sport in Society, 10(4), 560-579. doi:10.1080/17430430701388756

Darnell, S. C. (2010a). Power, politics and "sport for development and peace": Investigating the utility of sport for international development. Sociology of Sport Journal, 27(1), 54-75.

Darnell, S. C. (2010b). Sport, race, and bio-politics: Encounters with difference in "sport for development and peace" internships. Journal of Sport and Social Issues, 34(4), 396-417. doi:10.1177/0193723510383 141

Day, K., \& Devlin, R. A. (1998). The payoff to work without pay: Volunteer work as an investment in human capital. Canadian Journal of Economics, 31(5), 1179-1191. doi:10.2307/136465

Dierckx, D., Coene, J., Van Haarlem, A., \& Raeymaekers, P. (2013). Armoede en sociale uitsluiting. Jaarboek 2013 [Poverty and social exclusion. 2013 annual] 
(1st ed.). Leuven, Acco.

Dryfoos, J. G. (1990). Adolescents at risk: Prevalence and prevention (1st ed.). New York: Oxford University Press.

Dworkin, J. B., Larson, R., \& Hansen, D. (2003). Adolescents' accounts of growth experiences in youth activities. Journal of Youth and Adolescence, 32(1), 1726. doi:10.1023/A:1021076222321

Eley, D., \& Kirk, D. (2002). Developing citizenship through sport: The impact of a sport-based volunteer programme on young sport leaders. Sport, Education and Society, 7(2), 151-166. doi:10.1080/ 1357332022000018841

Eurostat. (2013). Retrieved from http://epp.eurostat.ec. europa.eu/portal/page/portal/eurostat/home

Eurostat. (2014). Retrieved from http://epp.eurostat.ec. europa.eu/portal/page/portal/eurostat/home

Feinstein L., Bynner J., \& Duckworth K. (2006). Young people's leisure contexts and their relation to adult outcomes. Journal of Youth Studies, 9(3), 305-327. doi:10.1080/13676260600805663

Fraser-Thomas, J., Côté, J., \& Deakin, J. (2005). Youth sport programs: An avenue to foster positive youth development. Physical Education and Sport Pedagogy, 10(1), 19-40. doi:10.1080/174089804200033 4890

Freire, P. (2008). Pedagogy of the oppressed (30th anniversary ed.). New York, NY: Continuum. (Original work published 1970)

Giulianotti, R. (2004). Human rights, globalization and sentimental education: The case of sport. Sport in Society, 7(3), 355-369. doi:10.1080/174304304200 0291686

Glover, T. D., \& Hemingway J. L. (2005). Locating leisure in the social capital literature. Journal of leisure research, 34(4), 387-401.

Guest, A. M. (2009). The diffusion of developmentthrough-sport: Analysing the history and practice of the Olympic Movement's grassroots outreach to Africa. Sport in Society, 12(10), 1336-1352. doi:10. 1080/17430430903204868

Hart, D., Donnelly, T. M., Youniss, J., \& Atkins, R. (2007). High school community service as a predictor of adult voting and volunteering. American Educational Research Journal, 44(1), 197-219. doi:10. 3102/0002831206298173

Hartmann, D., \& Kwauk, K. (2011). Sport and development : An overview, critique, and reconstruction. Journal of Sport and Social Issues, 35(3), 284-305. doi:10.1177/0193723511416986

Haudenhuyse, R., \& Theeboom M. (2008). Evaluatierapport Proeftuinproject Kort op de Bal [Evaluation report of the experimental garden Kort op de Bal]. Brussel: Vrije Universiteit Brussel.

Haudenhuyse, R., Theeboom, M., \& Coalter, F. (2012). The potential of sports-based social interventions for vulnerable youth: Implications for sport coaches and youth workers. Journal of Youth Studies, 15(4), 437-454. doi:10.1080/13676261.2012.663895

Haudenhuyse, R, Theeboom, M., \& Nols, Z. (2013). Sports-based interventions for socially vulnerable youth: Towards well-defined interventions with easy-to-follow outcomes? International Review for the Sociology of Sport, 48(4), 471-484. doi:10. $1177 / 1012690212448002$

Haudenhuyse, R., Theeboom, M., Nols, Z., \& Coussée, F. (2014). Socially vulnerable young people in Flemish sports clubs: Investigating youth experiences. European Physical Education Review, 20(2), 179198. doi:10.1177/1356336X13508686

Heckman, J. J. (2000). Policies to foster human capital. Research in Economics, 54(1), 3-56. doi:10.1006/ reec.1999.0225

Heckman, J. J. (2008). Schools, skills, and synapses. Economic inquiry, 46(3), 289-324. doi:10.1111/ j.1465-7295.2008.00163.x

Hellison, D. (1995). Teaching responsibility through physical activity (1st ed.). Champaign, IL: Human Kinetics.

Hellison, D., Walsh, D. (2002). Responsibility-based youth programs evaluation: Investigating the investigations. Quest, 54(4), 292-307. doi:10.1080/ 00336297.2002 .10491780

ILO. (2013). Global employment trends for youth 2013: A generation at risk. Geneva: International Labour Office Geneva.

Institute of Volunteering Research. (2002). Research bulletins: 1997 national survey of volunteering in the UK. Retrieved from http://www.ivr.org.uk/ nationalsurvey.htm

Johnson, M. K., Beebe, T., Mortimer, J. T., \& Snyder, M. (1998). Volunteerism in adolescence: A process perspective. Journal of Research on Adolescence, 8(3), 309-332. doi:10.1207/s15327795jra0803_2

Jones, S. (1985). Depth interviewing. In R. Walker (Ed.), Applied Qualitative Research (1st ed., pp. 45-55). Aldershot: Gower Publishing Company.

Kay, T., \& Bradbury, S. (2009). Youth sport volunteering: Developing social capital? Sport, Education and Society, 14(1), 121-140. doi:10.1080/135733208026 15288

Kidd, B. (2008). A new social movement: Sport for development and peace. Sport in Society, 11(4), 370380. doi:10.1080/17430430802019268

Kincheloe, J. L. (2008). Critical pedagogy primer (2nd ed.). New York: Peter Lang Publishing.

Lamote, C., Van Landeghem, G., Blommaert, M., Nicaise, I., De Fraine, B., \& Van Damme, J. (2013). Voortijdig schoolverlaten in Vlaanderen: een stand van zaken en een voorstel tot aanpak [Drop-outs from school in Flanders: Description of the current situation and the proposal of a new approach]. In M. Callens, J. Noppe, \& L. Vanderleyden (Eds.), De sociale staat van Vlaanderen (1st ed., pp. 13-60). 
Brussels: Studiedienst van de Vlaamse Regering.

Lerner, R. M., Lerner, J. V., Almerigi, J. B., Theokas, C., Phelps, E., Gestsdottir, S., Naudeau, S., Jelicic, H., Alberts, A., Ma, L., Smith, L. M., Bobek, D. L., Richman-Raphael, D., Simpson, I., DiDenti Christiansen, E., \& von Eye, A. (2005). Positive Youth Development, Participation in community youth development programs, and community contributions of fifth-grade adolescents findings from the first wave of the 4-H study of Positive Youth Development. The Journal of Early Adolescence, 25(1), 17-71. doi:10.1177/0272431604272461

Levermore, R. (2008). Sport: A new engine of development? Progress in Development Studies, 8(2), 183190. doi:10.1177/146499340700800204

MacNeela, P., \& Gannon, N. (2014). Process and positive development: An interpretative phenomenological analysis of university student volunteering. Journal of Adolescent Research, 29(3) 407-436. doi:10.1177/0743558413510968

National Research Council and Institute of Medicine. (2002). Community programs to promote youth development. Washington: National Academy Press.

OECD. (1998). Human capital investment: An international comparison. Paris: Organization for Economic Cooperation and Development, Centre for Educational Research and Innovation. Retrieved from http://browse.oecdbookshop.org/oecd/pdfs/free/9 698021E.PDF

Pawson, R. (2006). Evidence-based policy: A realist perspective (1st ed.). London: Sage.

Penner, L. A. (2002). Dispositional and organizational influences on sustained volunteerism: An interactionist perspective. Journal of Social Issues, 58(3), 447-467. doi:10.1111/1540-4560.00270

Putnam, R. D. (2000). Bowling alone: The collapse and revival of American community (1st ed.). New York: Simon and Schuster.

Rappaport, J. (1987). Terms of empowerment/ exemplars of prevention: Toward a theory for community psychology. American Journal of Community Psychology, 15(2), 121-148. doi:10.1007/ BF00919275

Risler, E. A., \& Holosko, M. J. (2009). Blueprint for a Youth Empowerment Model (YEM) through volunteerism. In E. S. C. Liu, M. J. Holosko, \& T. Wing Loa (Eds), Youth empowerment and volunteerism. Principles, policies and practices (1st ed., pp. 57-81). Hong Kong: City University of Hong Kong Press.

Schuller, T. (2001). The complementary roles of human and social capital. Canadian Journal of Policy Research, 2(1), 18-24.

Sharma, A. (2008). Logics of empowerment: Development, gender, and governance in neoliberal India (1st ed.). Minneapolis: University of Minnesota Press.

Smith, V. (2010). Enhancing employability: Human, cul- tural, and social capital in an era of turbulent unpredictability. Human Relations, 63(2), 279-300. doi:10.1177/0018726709353639

Sourbron, M., \& Herremans, W. (2013). Jeugdwerkloosheid in Europa: Vlaanderen in een Europees regionaal vergelijkend perspectief [Youth unemployment in Europe: Flanders within a European regional comparative perspective]. Leuven: Steunpunt Werk en Sociale Economie.

Spaaij, R. (2009). Sport as a vehicle for social mobility and regulation of disadvantaged urban youth: Lessons from Rotterdam. International Review for the Sociology of Sport, 44(2-3), 247-264. doi:10.1177/ 1012690209338415

Taylor, P. D., Panagoulas, T., \& Nichols, G. (2012). Determinants of sports volunteering and sports volunteer time in England. International journal of Sport policy and Politics, 4(2), 201-220. doi:10.1080/ 19406940.2012.656679

Tesch, R. (1990). Qualitative research analysis types and software tools (1st ed.). London: Routlegde Falmer.

Vanhoutte, B. (2007). Doe je mee? Jongeren en participatie aan het verenigingsleven [Are you in? Youth and participation in leisure associations]. In N. Vettenburg, M. Elchardus, \& L. Walgrave (Eds.), Jongeren in cijfers en letters. Bevindingen uit de JOPmonitor 1 (1st ed., pp. 175-187). Leuven: Lannoo.

Van Regenmortel, T. (2002). Empowerment en Maatzorg. Een krachtgerichte psychologische kijk op armoede [Empowerment and tailored care. A powerful psychological approach of poverty]. In J. Vranken, K. De Boyser, D. Geldof, \& G. Van Menxel (Eds.), Armoede en Sociale Uitsluiting, Jaarboek 2002 (1st ed., pp. 71-84). Leuven/leusden: Acco.

Van Regenmortel, T. (2009). Empowerment als uitdagend kader voor sociale inclusie en moderne zorg [Empowerment as a challenging framework for social inclusion and modern care]. Journal of Social Intervention: Theory and Practice, 18(4), pp. 22-42.

VDAB. (2012). Kansengroepen in kaart. Allochtonen op de Vlaamse arbeidsmarkt (2nd ed) [Target groups assessed. Immigrants on the Flemish labor market]. Retrieved from https://www.vdab.be/sites/web/files/doc/trends/K iK_allochtonen_2012.pdf

Vettenburg, N. (1998). Juvenile delinquency and the cultural characteristics of the family. International journal of adolescent medicine and health, 10(3), 193-210. doi:10.1515/IJAMH.1998.10.3.193

Vettenburg, N. (2011). Jongeren, maatschappelijke kwetsbaarheid en emancipatorisch Jeugdwerk [Youngsters, social vulnerability and emancipatory youth work. In F. Coussée, \& C. Mathijssen (Eds.), Uit de marge van het jeugdbeleid. Werken met maatschappelijk kwetsbare jeugd (1st ed., pp. 2538). Leuven: Acco. 
Weiss, C. H. (1997). How can theory-based evaluation make greater headway? Evaluation Review, 21(4), 501-524. doi:10.1177/0193841X9702100405

Wilson, J. (2000). Volunteering. Annual Review of Sociology, 26, 215-240. doi:10.1146/annurev.soc.26.1.215

Wilson, J., \& Musick, M. (1999). The effects of volunteering on the volunteer. Law and Contemporary Problems, 62(4), 141-168. doi:10.2307/1192270

Witt, P. A., \& Crompton, J. L. (1997). The protective factors framework: A Key to programming for benefits and evaluating for results. Journal of Park and Recreation Administration, 15(3), 1-18.

Woolcock, M. (2001). The place of social capital in understanding social and economic outcomes. Isuma: Canadian Journal of Policy Research, 2, 1-17.

Zimmerman, M. A. (2000). Empowerment theory: Psychological, organizational and community levels of analysis. In J. Rappaport \& E. Seidman (Eds.), Handbook of Community Psychology (1st ed., pp. 43-63). New York: Kluwer Academic/Plenum Publishers.

\section{About the Authors}
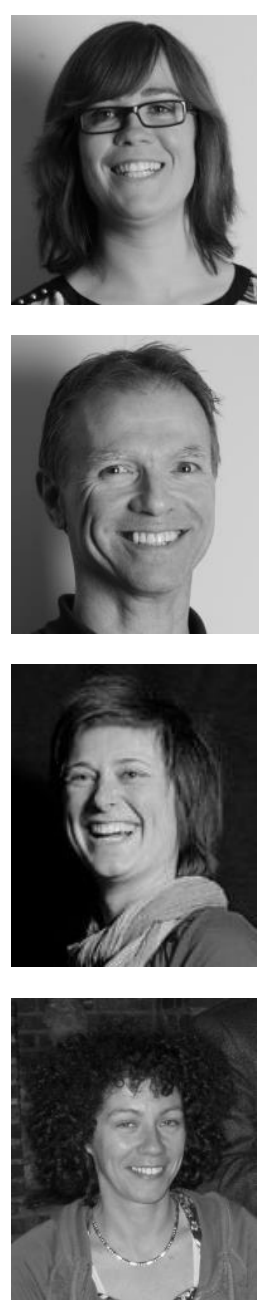

\section{Evi Buelens}

Evi Buelens works as a doctoral researcher at the Faculty of Physical Education and Physical Therapy of the Vrije Universiteit Brussel, Belgium (VUB). She is a member of the "Sport and Society" Research Group. Evi graduated in 2010 with high distinction as a master in Physical Education and Movement Sciences. Since January 2012, Evi has started her PhD-study within the scope of the Flemish Policy Research Centre on Sports. Her PhD-study is entitled: "Personal development of socially vulnerable youngsters through sports: exploring the potential role of volunteering".

\section{Prof. Dr. Marc Theeboom}

Marc Theeboom holds a PhD in Physical Education and a Master's degree in Leisure Studies. He works as a full professor at the Vrije Universiteit Brussel, Belgium (VUB). He is chair of the "Sport and Society" Research Group and of the Department of Sport Policy and Management. Since 2010, he has been the promoter-coordinator of the Flemish Policy Research Centre for Sports (Steunpunt Sport). His research primarily focuses on policy-related and pedagogical aspects of sport in general as well as in relation to specific target groups in particular.

\section{Dr. Jikkemien Vertonghen}

Jikkemien Vertonghen works as an assistant professor at the Department of Sports Policy and Management of the Vrije Universiteit Brussel (VUB), Belgium. In April 2011, Jikkemien received her PhD in Physical Education and Movement Sciences, in which she analyzed contextual factors in youth martial arts practice. Jikkemien's research is related to youth sports in general and martial arts practice in particular. She has a special interest in the analysis of sport programs in which sport is used as a tool to work with specific target groups towards personal, social and community development.

\section{Dr. Kristine De Martelaer}

Kristine De Martelaer is a professor at the Faculty of Physical Education and Physiotherapy, Vrije Universiteit Brussel (VUB, Belgium) where she is the head of the Department of Movement Education and Sports Training. She currently teaches sport history \& philosophy, didactics, curriculum PE (physical education) and first aid/basis life support. Her research is situated within pedagogy: didactical approaches, experiences and expectations of children and teachers/coaches with PE, youth sport and play, competences and job profile of PE teachers and youth coaches and ethics in (youth) sport. 